\title{
ISOLATION AND CHARACTERIZATION OF BACILLUS THURINGIENSIS FROM SOILS IN CONTRASTING AGROECOLOGICAL ZONES OF ETHIOPIA
}

\author{
Zeleke W. Tenssay ${ }^{1}$, Mogessie Ashenafi ${ }^{2}$, Alexander Eiler ${ }^{3}$ and Stefan Bertilson ${ }^{3}$ \\ ${ }^{1}$ Institute of Biodiversity Conservation, PO Box 30726 \\ Addis Ababa, Ethiopia. E-mail: otense2002@yahoo.co.uk \\ ${ }^{2}$ Aklilu Lemma Institute of Pathobiology, Addis Ababa University, Ethiopia \\ ${ }^{3}$ Evolutionary Biology Centre, Department of Limnology/Ecology and Evolution \\ Uppsala University, Sweden
}

\begin{abstract}
Phenotypic and molecular methods were used to isolate and characterize $B$. thuringiensis from diverse agro-ecological zones of Ethiopia. Bioassays were used to test the insecticidal activity of $B$. thuringiensis strains against the major malaria vector, Anopheles arabiensis (Diptera). B. thuringiensis were isolated from 32\% of the total 503 soil samples collected from the 16 agro-ecological zones. All sequenced isolates were $99 \%-100 \%$ identical to each other and to $B$. thuringiensis entries in Genbank. B. thuringiensis with similar 16S rRNA gene sequences from these different zones were characterized with regard to maximum growth rate and temperature optima for growth to test if there was local adaptation in these functional traits. The result showed a narrow temperature range around $30^{\circ} \mathrm{C}$ for maximal growth rate, and there were no significant differences between agro-ecological zones. Of 110 Bacillus thuringiensis isolates analyzed for the presence of crystal protein genes, 7 tested positive for cry 4, cry 11, and cyt toxin genes. Sequencing of these genes in positive strains demonstrated 99-100\% homology to known mosquitocidal cry and cyt genes in Bacillus thuringiensis subsp. israelensis. The present study shows that this biotechnologically important species is wide spread in Ethiopian soils and that it does not demonstrate local adaptation to temperature regimes, at least not for basic functions such as growth-temperature response. Our finding also pointed the potential for exploiting this species in vector control programs.
\end{abstract}

Key words: Agroecological zone, Bacillus thuringiensis, crystal protein gene, mosquitocidal

\section{INTRODUCTION}

B. thuringiensis strains have been isolated worldwide from many habitats, including soil, insects, stored-products, dust and deciduous and coniferous leaves (Carozzi et al., 1991; Smith and Couche, 1991; Chilcott and Wigley, 1993; Yoo, et al., 1996; Hansen et al., 1998; Cavado et al., 2001). A typical method of isolation involves heat treatment to select for spores, sometimes with an acetate enrichment step (Travers et al., 1987), antibiotic selection (Yoo et al., 1996) or non selective agar media (Chilcott and Wigley, 1993).

Ethiopia is considered to be one of the richest genetic resource centers in the world in terms of crop diversity. Although there is a lack of information on microbial diversity, it is believed that Ethiopia's heterogeneous environmental conditions also promote the diversity of microbial communities. Despite the need for information on genetic diversity of indigenous strains of $B$. thuringiensis for potential use in biocontrol programs, studies addressing these issues are scarce in Ethiopia. Some workers tested commercial preparations of $B$. thuringiensis (Dipel) on crop pests against cutworms (Agrotis spp.) and Stalkborer (B. fusca) in cereals and potato tuber-worm on tomatoes (Alemayehu Refera et al., 1993). A similar study was carried out on B. thuringiensis var kurstaki isolates against African bollworm, Helicoverpa armigera (Alemayehu Refera et al., 1993). Results from these studies were not encouraging from a biocontrol perspective, but it has been shown that standard $B$. thuringiensis subspecies israelensis were active against Anopheles arabiensis from Ethiopia (Aklilu Seyoum and Dawit Abate, 1997).

The objective of the present study was to isolate and characterize $B$. thuringiensis from diverse agro-ecological zones of Ethiopia and test the strains against the major malaria vector in Africa. 


\section{MATERIALS AND METHODS}

\section{Study area}

Ethiopia is regionally divided into 18 major agro-ecological zones and 49 sub zones (MOA, 2000). The term "agro-ecological zone" is used to describe the broad temperature, moisture, and latitude for different regions. The major zones are sub divided into sub-zones which are more homogenous in terms of climate, physiographic, soils, vegetation, land use, farming system, and animals. Soil samples were collected from 16 accessible major agro-ecological zones (Table 1).

\section{Sampling methods}

Surface soil was scraped off to avoid surface contamination and about 200 grams of soil samples were taken from a depth of 4-10 cm with sterile spoons and subsequently transferred into sterile plastic bags. Duplicate soil sample was taken from each selected field in different agro-ecological zones.

\section{Processing of soil samples}

Soil samples (10 g) were individually suspended in $100 \mathrm{ml}$ sterile water and homogenized with a magnetic stirrer for 10 minutes. Serial dilutions in tenfold step up to $10^{5}$ were made and the dilutions were heated at $80^{\circ} \mathrm{C}$ for 10 minutes in a water bath equipped with shaker to destroy non-spore formers and vegetative Bacillus cells. Aliquots of $0.1 \mathrm{ml}$ soil slurries were individually plated on Nutrient Agar and incubated aerobically at $28^{\circ} \mathrm{C}$ for $48-72$ hours.

\section{Microscopic examination of culture}

After 48 hours of incubation, bacterial colonies on the plates were visually examined. Colonies showing morphological features such as being large, dry, flat, or sticky, characteristics typical for the $B$. cereus- $B$. thuringiensis group, were picked and transferred to Nutrient broth. Inoculated tubes were incubated aerobically for 4 hours at $28^{\circ} \mathrm{C}$ and sub-cultured on Nutrient agar to check for purity of the isolate. The Nutrient agar culture was incubated for 48-72 hours aerobically at $28^{\circ} \mathrm{C}$. Smears were prepared from the culture, and differentially stained with a method originally reported by Chilcott and Wigley (1988). Phase contrast, and Differential Interference Contrast microscopic observation at 1000x magnification using a Nowarski Optics Microscope fitted with a Hamamatsu Orcca IIIm camera and OPeulab3.0.9 software used to confirm the differential stained observation.

Table 1. Agro-ecological zones where samples were taken, annual average temperature, rainfall and dominant soil type.

\begin{tabular}{|c|c|c|c|c|c|}
\hline Code & Agroecological zone & Sampling Area & Temp & $\begin{array}{l}\text { Mean annual } \\
\text { Rainfall }\end{array}$ & Main soil type \\
\hline A1 & Hot to warm arid low land & Afar, Diredawa & $16-21$ & $300-800$ & Eutric, Regosols, \\
\hline $\mathrm{H} 1$ & Hot to humid low land & Derashe & $18-24$ & $1200-1500$ & Dystric Nitosols \\
\hline $\mathrm{H} 2$ & Tepid to cool humid high land & Gore, Bedele, Metu, Jimma & $11-21$ & $700-2200$ & Dystric Nitosols \\
\hline M1 & Hot to warm moist low land & AsebeTeferi,Metahara & $16-27$ & $600-1600$ & Orthic Acrisols \\
\hline M2 & Tepid to cool moist mid-high land & Ambo, Dejen, Fiche, etc & $11-21$ & 1000-1800 & Vertisols, Nitosols \\
\hline M3 & Cold to very cold moist sub afroalpine & Quarit, Amhara regions & $7.5-11$ & $1000-1800$ & Phaeozems, Leptisols \\
\hline PH1 & Hot to warm per-humid low land & Bench Maji Zone & $24-26$ & $1100-1500$ & Eutric Fluvisol \\
\hline PH2 & Tepid to cool per-humid mid-high land & Keficho Shekicho Zone & $14-25$ & $1100-2200$ & Dystric Nitosol \\
\hline SA1 & Hot warm sub moist mid-high land & Humera & $21-28$ & $300-800$ & Vertisols \\
\hline SH1 & Hot to warm sub-humid lowland & Bebeka, Arbaminch & $16-28$ & $00-1000$ & Vertisol, Fluvisol \\
\hline SH2 & Tepid to cool sub-humid mid high land & Harari, Alemaya & $11-21$ & $700-2200$ & Dystric Nitosols \\
\hline SH3 & Cold to very cold sub-humid sub afro-alpine & South west Chencha & $7.5-15$ & $700-1500$ & Humic Cambisols \\
\hline SM1 & Hot to warm sub-moist low land & Metema & $>21$ & $200-1000$ & Vertisols ambisols \\
\hline SM2 & Tepid to cool sub-moist mid high land & Nazeret, Mojo, DebreZeit & $11-21$ & $700-1200$ & Vertic andosols \\
\hline SM3 & $\begin{array}{l}\text { Cold to very cold sub-miost sub afro-alpine } \\
\text { to afro-alpine }\end{array}$ & Feres Bet, Workamba & ND & ND & Haplic Phaeozems \\
\hline
\end{tabular}




\section{$16 S$ rRNA gene sequencing}

DNA was isolated using the DNeasy DNA extraction kit (Qiagen, Hilden, Germany) following the protocol for gram positive bacteria provided by the manufacturer. 16S rRNA genes were amplified using primer 27f (Vergin et al., 1998) and 1492r (Lane, 1991). Between 1ng $\mu \mathrm{l}^{-1}$ and $8 \mathrm{ng} \mu \mathrm{l}^{-1}$ of genomic DNA from each isolate was added to $20 \mu \mathrm{l}$ reactions containing PCR buffer (buffer specification of DyNAzyme), 100 $\mathrm{nM}$ of each primer, $200 \mathrm{mM}$ of each dNTP and 0.25 U DyNAzyme II Polymerase (Finnzymes OY; Espoo, Finnland). PCR conditions were as follows: initial denaturation at $94^{\circ} \mathrm{C}$ for $3 \mathrm{~min}$ followed by 30 cycles of $1 \mathrm{~min}$ at $94^{\circ} \mathrm{C}, 1 \mathrm{~min}$ annealing at $55^{\circ} \mathrm{C}$ and 2 min primer extension at $72^{\circ} \mathrm{C}$ and a final extension at $72^{\circ} \mathrm{C}$ for $7 \mathrm{~min}$. PCR products were diluted at least 5 times with $\mathrm{Q}$ grade water to a final concentration of

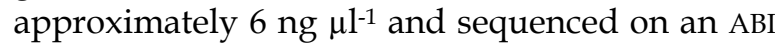
3700 96-capillary sequencer (Applied Biosystems) using primer 27f (Vergin et al., 1998) and the BigDye terminator kit vs. 3.1 (Applied Biosystems). This generated high-quality reads of 500-900 bp. The gene sequences were compared to GenBank entries using BLAST (Basic Local Alignment Tool) and imported into ARB and then automatically aligned using the integrated aligner tool and the fast aligner option, followed by manual alignment of the sequences to $B$. thuringiensis entries. A maximum likelihood tree was constructed with ARB (Strunk and Ludwig, 1996). All sequences have been deposited in Genbank under accession numbers: EF 113600-EF 113708.

\section{Temperature dependant growth response}

Confirmed B. thuringiensis isolates were tested for their growth rate response to temperature. $B$. thuringiensis isolates were cultured on LB medium and incubated at $28^{\circ} \mathrm{C}$ overnight. Inocula from these cultures were separately transferred to 200 $\mu \mathrm{l}$ LB broth and incubated at $28^{\circ} \mathrm{C}$ overnight. For each isolate, $2 \mu \mathrm{l}$ of each isolate was transferred to Bioscreen $\mathrm{C}$ multiwell plates for analytical incubations at temperatures ranging from $11^{\circ} \mathrm{C}$ to $40^{\circ} \mathrm{C}$. Incubations and continuous readings of optical density at $600 \mathrm{~nm}$ maximal growth recordings were carried out in a Bioscreen $C$ Reader (OY Growth curves AB Ltd, Helsinki, Finland). A flow cytometric determination of bacterial abundance originally devised by delGiorgio et al. (1996) was used to estimate abundance of $B$. thuringiensis. Optical density reading versus cell number estimated by flow cytometry was used to plot regression line and from these data maximal growth rate was calculated. Maximal growth rate of isolates from different agro-ecological zones were compared by one way ANOVA using SPSS version 11.0.

\section{Crystal protein gene determination}

A loopful of Bacillus thuringiensis isolates grown aerobically on LB media overnight at $30^{\circ}$ C, were transferred to individual $2 \mathrm{ml}$ eppendrof tubes and stored at $-80^{\circ} \mathrm{C}$ for DNA extraction. DNA extraction was carried out using the DNeasy kit from Qiagen (Carlsbad, CA) according to the protocol for isolation of genomic DNA from gram positive bacteria. Reference Bacillus thuringiensis strains were obtained from the Bacillus Genetic Stock Center (Ohio University, USA). These were Bacillus thuringiensis subsp. kurtstaki HD 1, Bacillus thuringiensis subsp. kenyae HD136 (HDB-23), Bacillus thuringiensis subsp. israelensis ONR60A, and Bacillus thuringiensis biovar.tenebrionis.

General primers for crystal protein genes selected from highly conserved regions of the different classes of cry genes by multiple alignments of all reported DNA sequences (BenDov et al., 1997; Bravo et al., 1998) obtained from MWG-Biotech AG. These pairs of primers were gral-cry1, gral-cry 4, gral-cry 8, gral-cry11, gralcry-nem (nematocidal cry genes), gral-cyt, and universal Un-cry2, Un-cry3 Un-cry7 and Un-cry8.

Amplification was carried out for 30 cycles in a Stratagene Robocycler, where each $25 \mu$ l reaction contained $2 \mu \mathrm{l}$ of DNA extract (1-4 $\mu \mathrm{g}$ template DNA), reaction Buffer $(10 \mathrm{mM}$ Tris- $\mathrm{HCl} \mathrm{pH} 8.8$, $1.5 \mathrm{mM} \mathrm{MgCl} 250 \mathrm{mM}$ and $\mathrm{KCl} 0.1 \%$ Triton X100), $150 \mu \mathrm{M}$ of each deoxynucleoside triphosphate, $0.2 \mu \mathrm{M}$ of each primer, and $0.5 \mathrm{U}$ of Dynozyme II DNA polymerase (Finnzymes, Finland). PCR conditions were set according to the original references as given below: for cry 1 gene (with general primers, gral-cry1) a single initial denaturation at $95^{\circ} \mathrm{C}$ for 2 minutes, followed by 30 cycles with denaturation at $95^{\circ} \mathrm{C}$ for 1 minute, annealing at $52^{\circ} \mathrm{C}$ for 1 minutes, and extension at $72^{\circ} \mathrm{C}$ for 1 minute, and an additional extension at $72^{\circ} \mathrm{C}$ for 5 minutes. PCR conditions for the other crystal protein genes were identical except variable annealing temperatures were applied; 49 ${ }^{\circ} \mathrm{C}$ for cry $8,51^{\circ} \mathrm{C}$ for cry 11 and $c y t$, and $50^{\circ} \mathrm{C}$ for cry nem- primers.

All PCR products obtained were sequenced for confirmation and identification of the specific sub-class of the genes. Briefly, $5 \mathrm{ng}$ of the PCR products were mixed with $1.6 \mathrm{pmol}$ of the respective cry/cyt gene forward primer and sequenced on an ABI 3700 96-capillary sequencer (Applied Biosystems) using the BigDye 
terminator kit v.3.1 (Applied Biosystems). Sequences were deposited in GenBank under accession numbers EF649739-EF649757 and compared to Genbank entries using BLAST (Basic Local Alignments Tool; Altschul et al., 1997).

\section{Bioassay against An. arabiensis (Diptera)}

Biological activity of spore-crystal inclusion complexes of $B$. thuringiensis was tested against An. arabiensis as described by previous workers (Cavado et al., 2001). Briefly, $5 \mathrm{ml}$ of Spore-crystal suspension containing approximately $1.5 \times 10^{8}$ spores $/ \mathrm{ml}$ prepared in $0.85 \%$ saline solution was transferred to each duplicate beaker containing 10 larvae in $50 \mathrm{ml}$ chlorine free water. The larvae were kept at room temperature for up to 48 hours. B. thuringiensis sub-species israelensis (ATCC35646) was used as positive control; and larvae in chlorine free water without spore crystal suspension served as negative control. The dead larvae were recorded at 24 and 48 hours.

\section{RESULTS}

Morphological characterization of $\mathbf{B}$. thuringiensis

Mixed bacterial colonies were observed on examination of 48 hour cultures on nutrient agar plates. Gram staining of colonies with big, dry, sticky characteristics, revealed Gram positive rods with refractile spores that do not swell the cells. Differential stain and phase contrast microscopy revealed faint crystal protein inclusion, refractile spores, and vegetative cells (Fig. 1).
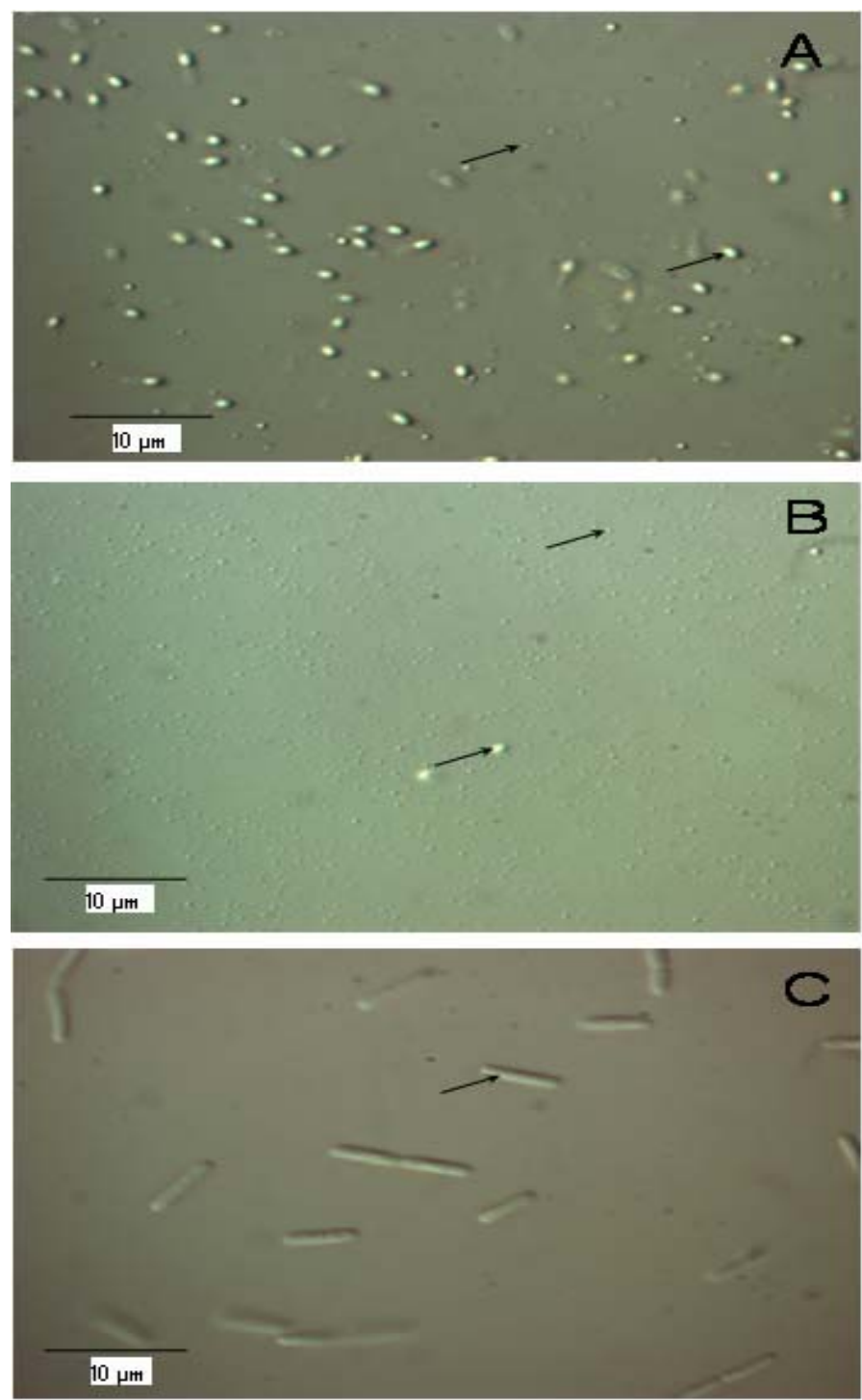

Fig. 1. Differential interference contrast microscopy (1000x) photograph of protein inclusion, vegetative cell and spore of Bt isolates. Arrows A and B indicate spores (bright) and crystal inclusion (faint); C, Vegetative cells (faint). 


\section{Molecular characterization of B. thuringiensis by $16 S$ rRNA sequencing}

From a total of 161 putative $B$. thuringiensis isolates, 16S rRNA genes sequences were obtained from 110 isolates, with at least one representative from each of the 16 different agro-ecological zones of Ethiopia. For all sequences, BLAST search showed $99-100 \%$ similarity to B. thuringiensis entries in Genbank. Maximum likelihood analysis revealed that $B$. thuringiensis isolates from agro-ecological zones of Ethiopia were closely related.

\section{Temperature-growth response}

B. thuringiensis isolates with similar 16S rRNA gene sequences were tested for growth rate response to temperature. This fundamental physiological trait could be expected to vary between geographical zones as a result of adaptation to prevailing temperature regimes. The average maximal growth rate of isolates from Hot to Warm agro-ecological zones ranged from 2.4 (SM1) to 3.3 generations hour-1 (Ph1) and the temperature at which these average maximal growth rates observed was $30^{\circ} \mathrm{C}$ (Fig. 2).

$$
\text { ปั. }
$$
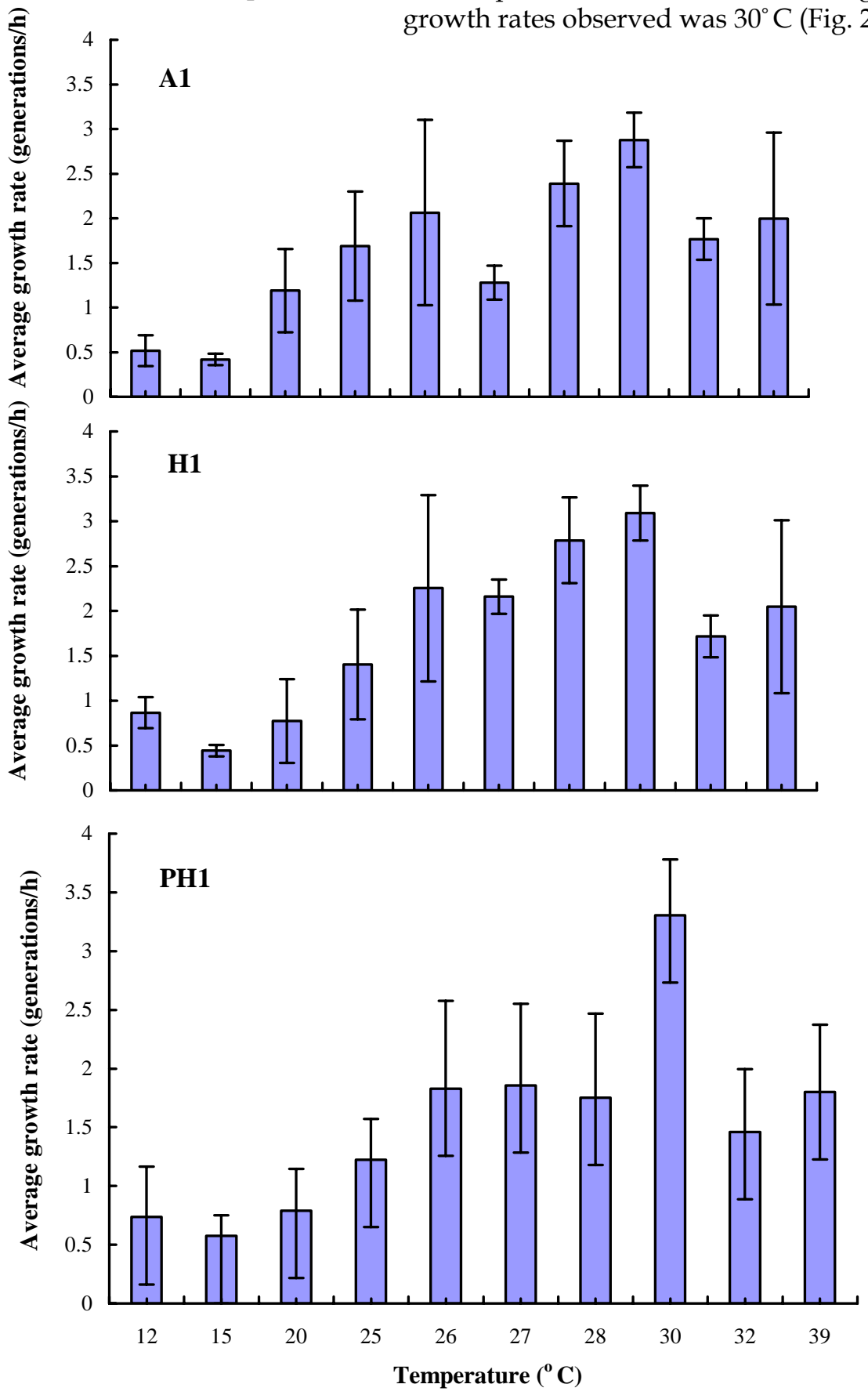

Fig. 2. Growth rate of Bt isolates from hot to warm AEZ of Ethiopia. Growth rate was determined from regression line plotted using data from optical density versus cell number estimated by flow cytometry; AEZ, agro-ecological zone; A1,hot to warm arid lowland; H1,hottowarm humid lowland; Ph1, hot to warm per humid lowland. 
The average maximal growth rate for isolates from Tepid to Cool agro-ecological zones ranged from $2.2(\mathrm{H} 2)$ to 2.9 generations hour $^{-1}(\mathrm{M} 2)$. The temperatures at which these average maximal growth rates were achieved ranged from $26^{\circ} \mathrm{C}$ to $30^{\circ} \mathrm{C}$ (Fig. 3). Growth rate of Bt isolates from cold to very cold agroecological zones is shown in Figure 4 .
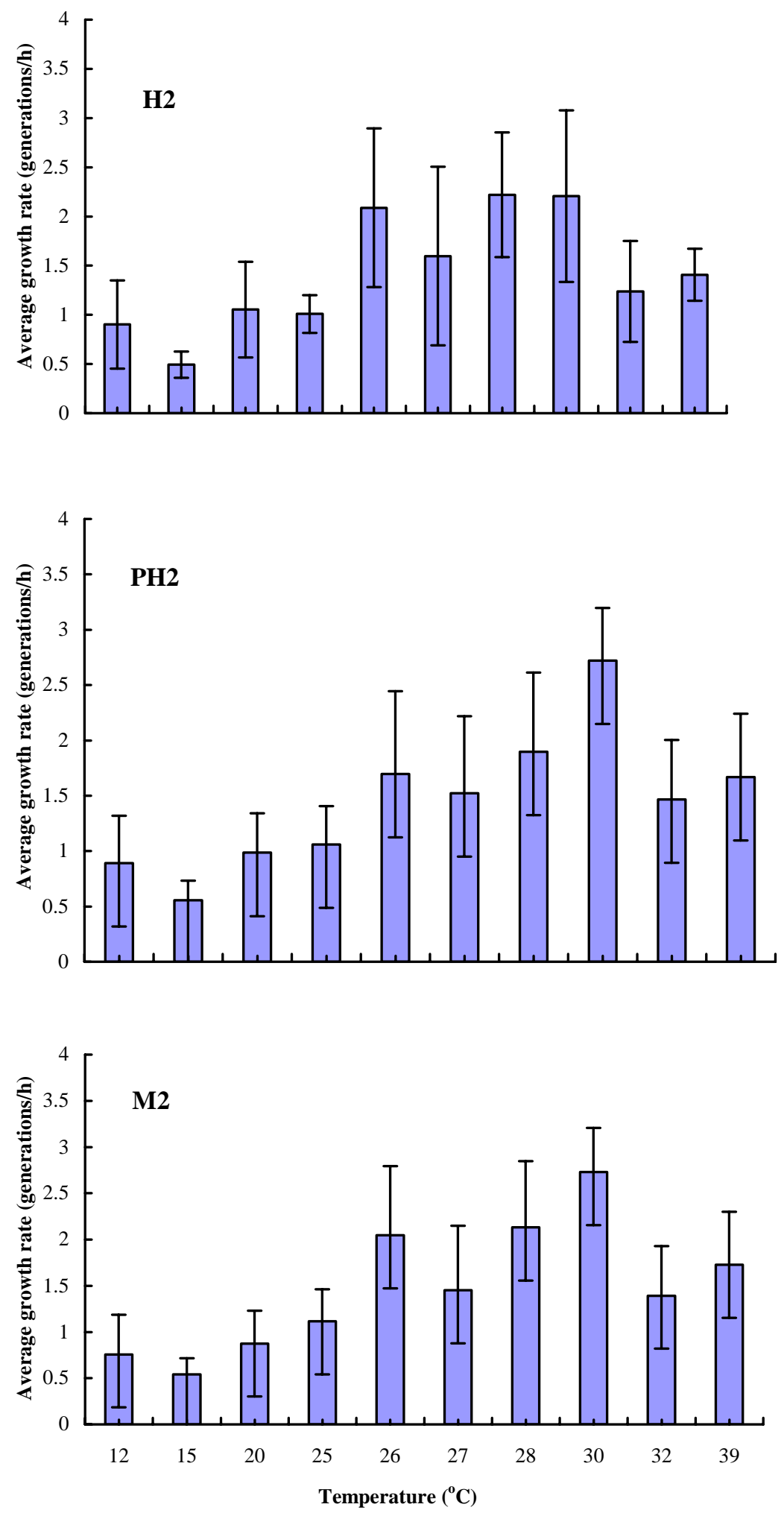

Fig. 3. Growth rate of Bt isolates from tepid to cool AEZ of Ethiopia Growth rate was determined from regression line plotted using data from optical density versus cell number estimated by flow cytometry; $\mathrm{H} 2$, tepid to cool humid highland; $\mathrm{Ph} 2$, tepid to cool perhumid mid highland; M2, tepid to cool moist mid highland. 

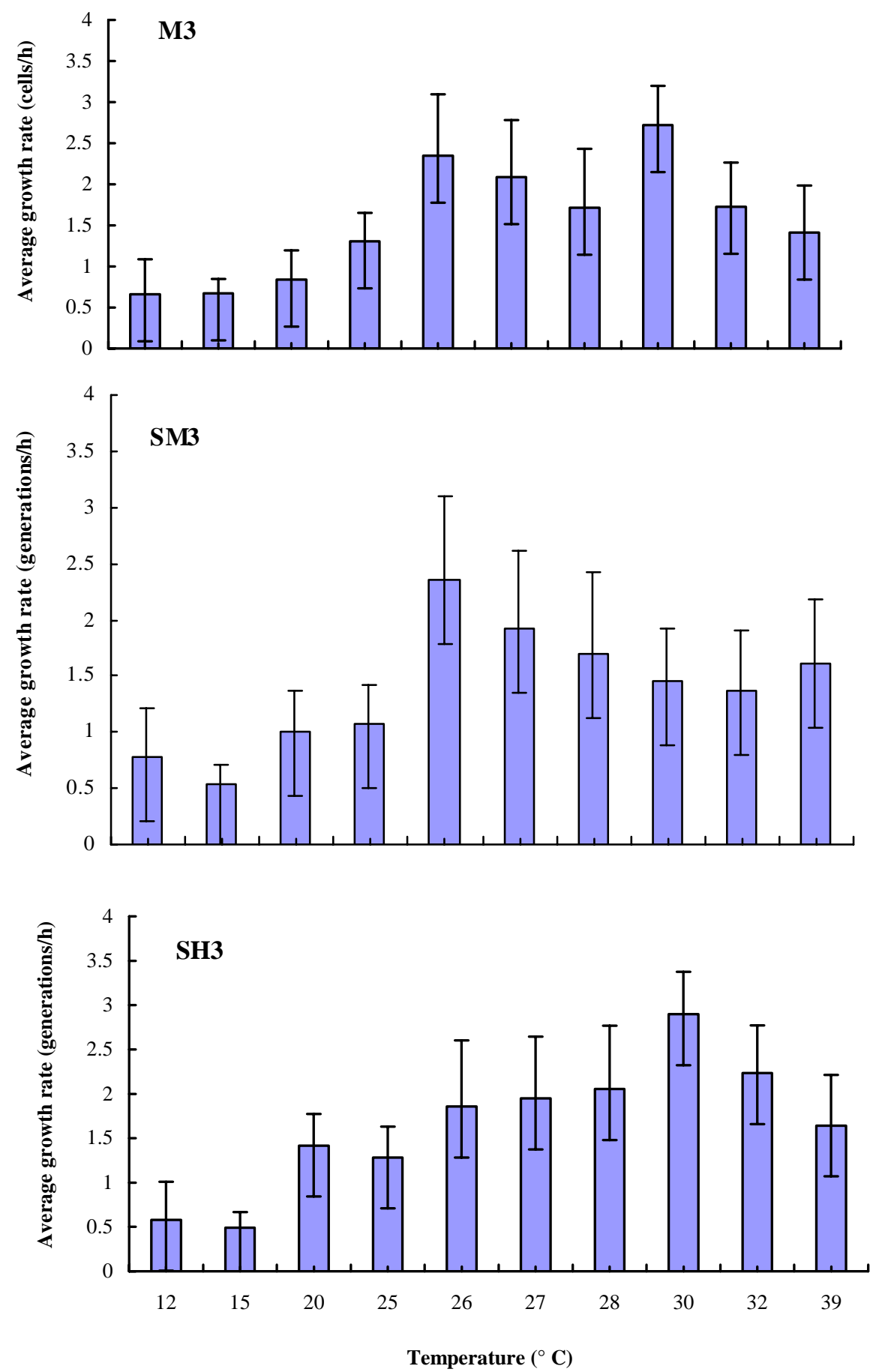

Fig. 4. Growth rate of Bt isolates from cold to very cold AEZ. Growth rate was determined from regression line plotted using data from optical density versus cell number estimated by flow cytometry; M3,cold to very cold moist sub afroalpine; SM3, cold to very cold sub moist sub afroalpine; $\mathrm{SH}$, cold to very cold sub humid sub afroalpine.

\section{Larvicidal property}

A total of 213 B. thuringiensis-B. cereus strains were screened for their toxicity against the malaria vector, $A$. arabiensis. Of these, $43(20.8 \%)$ killed $50-100 \%$ of the larvae within 48 hours. Out of the 43 strains, 12 killed $100 \%$ of the larvae within 24 hours, and 12 killed $100 \%$ larvae within 48 hours (Table 2 ). 
Table 2. Activity of Bt against Anopheles arabiensis larvae.

\begin{tabular}{|c|c|c|c|}
\hline AEZ & Bt strain & $\begin{array}{r}\% \text { larvae } \\
\text { killed (24h) }\end{array}$ & $\begin{array}{r}\% \text { larvae } \\
\text { killed }(48 \mathrm{~h})\end{array}$ \\
\hline M2 & FGW & 100 & 0.0 \\
\hline- & FGB & 100 & 0.0 \\
\hline- & FGJB & 40 & 40.0 \\
\hline- & GDMC2 & 100 & 0.0 \\
\hline- & DKF & 100 & 0.0 \\
\hline- & BYW2 & 100 & 0.0 \\
\hline- & GMAS & 55 & 65.0 \\
\hline- & FWAW & 90 & 90.0 \\
\hline - & GIAT2 & 90 & 90.0 \\
\hline- & GAS & 65 & 80.0 \\
\hline- & GDBm & 95 & 95.0 \\
\hline - & GDFW2 & 100 & 0.0 \\
\hline- & GIP & 100 & 0.0 \\
\hline- & ISGP & 90 & 90.0 \\
\hline- & FGJW2 & 85 & 85.0 \\
\hline - & KWB2 & 95 & 100.0 \\
\hline- & DEP2 & 100 & 0.0 \\
\hline - & $\mathrm{DDN}$ & 100 & 0.0 \\
\hline - & FGT & 100 & 0.0 \\
\hline- & DGS & 100 & 0.0 \\
\hline- & FWO & 100 & 0.0 \\
\hline SH1 & BBGB & 45 & 50.0 \\
\hline- & BBGB2 & 70 & 70.0 \\
\hline- & DTAM & 75 & 100.0 \\
\hline- & DTAG & 80 & 100.0 \\
\hline- & AKC & 90 & 100.0 \\
\hline SM3 & GDFT & 85 & 95.0 \\
\hline- & GWMN & 50 & 55.0 \\
\hline - & GDFb & 70 & 90.0 \\
\hline- & GWMN2 & 90 & 90.0 \\
\hline M3 & QDT2 & 90 & 95.0 \\
\hline- & QGT2 & 95 & 95.0 \\
\hline $\mathrm{H} 2$ & JGSn & 50 & 95.0 \\
\hline- & IBKT & 55 & 95.0 \\
\hline- & IYM & 90 & 100.0 \\
\hline - & IGDN & 65 & 100.0 \\
\hline- & JDGI2 & 70 & 100.0 \\
\hline- & IBKT2 & 75 & 95.0 \\
\hline- & JGHS2 & 95 & 100.0 \\
\hline - & JGP & 55 & 100.0 \\
\hline- & JGTN & 60 & 100.0 \\
\hline $\mathrm{SH} 2$ & SDI & 90 & 100.0 \\
\hline- & DMAB2 & 60 & 100.0 \\
\hline PH2 & SMGB & 75 & 75.0 \\
\hline PH1 & BSWC & 70 & 70.0 \\
\hline
\end{tabular}

Ten larvae of An. arabiensis were exposed to each Bt strain; and all tests were carried out in duplicate.

\section{Presence of cry genes}

One hundred and ten $B$. thuringiensis isolates were analyzed for the presence of cry genes. Seven isolates were positive for each of cry 4, cry 11 , and cyt toxin genes whereas none of the isolates were positive for cry 1, cry 2, cry3 3 cry7, cry 8 , and nematocidal cry genes. The most frequent cry genes sub-class were cry $11 \mathrm{AA}$, cry
4AA and cyt 1AA (Table 3). In most cases, cry genes occurred in combination with each other in the present collection of isolates. The sequences of these genes (GenBank Accession numbers EF649739-EF649750) were, with two exceptions, 99-100 \% identical to Bacillus thuringiensis subsp. israelensis mosquitocidal cry and cyt genes. 
Table 3. Crystal protein gene profiles of Bacillus thuringiensis isolates from Agro-ecological Zones of Ethiopia.

\begin{tabular}{llllllc}
\hline AEZ & Sample area & Bt Strain & cry11 & cry4 & cyt & \% of larvae killed \\
\hline M2 & Guraketeba, Fiche & FGW2 & $11 \mathrm{Aa}$ & $4 \mathrm{AA}$ & $1 \mathrm{AA}$ & 100 \\
M2 & Guraketeba, Fiche & FGB & $11 \mathrm{AA}$ & $4 \mathrm{Aa}$ & $\mathrm{Ng}$ & 100 \\
M2 & Enajima, Dejen & DEP2 & $11 \mathrm{Aa}$ & $4 \mathrm{AB}$ & $1 \mathrm{AA}$ & 100 \\
M2 & Guraketeba, Fiche & FGW & $11 \mathrm{AA}$ & $4 \mathrm{AA}$ & $\mathrm{Ng}$ & 100 \\
M2 & Wuchalejida, Fiche & FWO & $11 \mathrm{AA}$ & M39* & 1 cyt & 100 \\
M2 & Dembeza, Dejen & DDN & $11 \mathrm{AA}$ & $4 \mathrm{AA}$ & $1 \mathrm{AA}$ & 100 \\
M2 & Yetemen, Bichena & BYW2 & $11 \mathrm{AA}$ & $4 \mathrm{AA}$ & $1 \mathrm{AA}$ & 100 \\
\hline
\end{tabular}

$c r y=$ crystal protein gene; $c y t=$ cytolytic gene; $\%$ killed $=\%$ Anopheles arabiensis killed after $24 \mathrm{~h}$. M39* $=92 \%$ identical to mosquitocidal toxin gene subsp. kurstaki cry $39,1 \mathrm{cyt}^{* *}=$ unclassified cytolytic gene. M2, denotes tepid to cool agroecological zone in Ethiopia. $\mathrm{Ng}=$ ambiguous sequence; soil samples were collected from crop fields which included wheat, barely, potato, onion except in Dembeza, Dejen which was natural vegetation.

\section{DISCUSSION AND CONCLUSIONS}

In the present study, morphological, physiological, and molecular methods coupled with biological activity were used to characterize $B$. thuringiensis isolates from soils collected from contrasting agro-ecological zones of Ethiopia. Based on heat-resistance and colony morphology alone, it was possible to discriminate $213 B$. cereus- $B$. thuringiensis-like bacilli. Out of these, 161 isolates contained crystal protein inclusions. Although the use of a single character, such as crystal inclusions, for classification has been criticized (Helgason et al., 2000), many studies rely on crystal inclusions as the only characteristic feature that distinguishes $B$. thuringiensis from B. cereus (Bernhard et al., 1997; Rasko et al., 2005). Comparison of the 16S rRNA gene sequences of our isolates with the GenBank BLAST entry showed 99 to $100 \%$ similarity to $B$. cereus- $B$. thuringiensis group organisms. Blackwood et al., (2004) analysed 16S rRNA gene sequences from Bacillus species and reported that members of the B. cereus group had 100\% sequence identity across the 16S rRNA gene. Similarly Goto et al. (2000) and Helgason et al. (2000) compared 16S rRNA gene sequences of the $B$. cereus group and reported that the sequences were highly conserved, with homologies ranging from 92.2-99.6\% identity. These workers indicated that members of $B$. cereus group could not be distinguished from each other. In the present study, we based our identification on a combination of $16 \mathrm{~S}$ rRNA gene sequencing and microscopic identification of crystal protein inclusions.

When comparing $B$. thuringiensis from different agro-ecological zones of Ethiopia, we expected isolates from colder temperature zones to shift the optimum temperature for growth towards lower temperatures compared to isolates from warmer regions if there was indeed adaptation with regard to this environmental characteristic. Although isolates from different agro-ecological zones grew well across the entire temperature range $\left(12-39^{\circ} \mathrm{C}\right)$, almost all isolates showed maximal growth rate around $30^{\circ} \mathrm{C}$. The average temperature for reaching maximum growth rates was not significantly different between agroecological zones $(\mathrm{P}>0.05)$. This may be due to either limited physiological potential for adaptation or the result of the typically broad temperature range observed within each agroecological zone. The response of our $B$. thuringiensis to a set of temperatures is comparable to observations on enteric bacteria by researchers elsewhere (Bronikowski et al., 2001; Shi and Xia, 2003). Bronikowski et al.( 2001) studied effect of temperature on growth rate in natural isolates of E. coli and Salmonella from different thermal environments with special interest in questions such as whether optimal temperature and thermal niches of bacterial flora reflected seasonal, geographic or phylogenetic differences in their hosts temperature. Their results suggested that these bacterial species were thermal generalists and did not track fine scale changes in their thermal environments. 
In the present study, seven out of 110 isolates tested positive for the presence of crystal protein genes (cry4, cry11, cyt) whereas none tested positive for cry 1, cry 2, cry3, cry 7 and 8 , and nematocidal cry genes. Amplified cry genes had $99-100 \%$ sequence identity to those of $B$. thuringiensis subsp. israelensis except for one strain with cry sequence identity of $92 \%$ to cry 39 of $B$. thuringiensis subsp. kurstaki. The former reference strain carries six genes coding for toxic proteins on a $137 \mathrm{kDa}$ plasmid. The expressed genes include cry $4 \mathrm{~A}$, cry $4 \mathrm{~B}$, and cry $10 \mathrm{~A}$ (former cry IVC), cry 11A (formerly cry IVD), cyt 1A, and cyt 2A (Rangni et al., 1996; Ibarra and Federici., 2003). Each of these cry- gene-encoded toxin components in B. thuringiensis subsp. israelensis is mosquitocidal.

Our result showed that $43(20.8 \%)$ of the isolated spore forming bacilli with crystal inclusion morphology killed $50-100 \%$ of the tested An. arabiensis larvae within 48 hours. Insect species, against which biological activity of B. thuringiensis is evaluated, differ from one laboratory to another, so it is difficult to get data of similar insect bioassay to compare mortality level on a large scale. Some workers (Porter et al., 1993) compared the susceptibility of mosquito species and indicated that in general species of Aedes and Culex were more sensitive than species of Anopheles to B. thuringiensis subsp. israelensis. A study from Ethiopia (Aklilu Seyoum, 1995) compared the efficacy of $B$. thuringiensis subsp. israelensis against $A n$. arabiensis and $C x$. quinquefaciatus and reported that $A n$. arabiensis was more susceptible than $C x$. quinquefaciatus. Aklilu Seyoum and Dawit Abate (1997) tested the larvicidal activity of a standard strain of $B$. thuringiensis subsp. israelensis IPS-82 against $A n$. arabiensis larvae in Ethiopia and concluded that the malaria vector was highly susceptible.

The finding of $B$. thuringiensis isolates carrying cry protein toxin genes while also expressing insecticidal activity against the malaria vector An. arabiensis is promising in the context of indigenous development, production and application of biological control agents against disease vectors in African countries. These isolates may be particularly suited to be applied in these regions as bacteria should be adapted to prevailing environmental conditions as well as the particular insect species targeted. The large number of crystal protein inclusion-containing $B$. thuringiensis/cereus that tested negative for known cry and cyt genes may indicate the presence of novel toxins or toxin variants. Thus, detailed studies are required to characterize such strains of Bacillus thuringiensis.

\section{ACKNOWLEDGEMENTS}

The research was carried out in Addis Ababa University and Uppsala University, Sweden, as part of the PhD study of the first author. The following institutions are acknowledged for their help: Addis Ababa University Research and Graduate Study Programs Office, for funding the study, Entomology Unit, Aklilu Lemma Institute of Pathobiology, AAU, for providing dipteran larvae, Department of Biology, $\mathrm{AAU}$, for the training program and the Swedish Institute for offering Guest Scholarship.

\section{REFERENCES}

1. Aklilu Seyoum and Dawit Abate (1997). Larvicidal efficacy of $B$. thuringiensis var israelensis and $B$. sphaericus on Anopheles arabiensis in Ethiopia. World J. Microbiol. Biotechnol. 13:21-24.

2. Aklilu Seyoum (1995). Mosquito larvicidal Bacillus strains from Ethiopia. A thesis presented to the school of gradate studies, Addis Ababa, Ethiopia.

3. Alemayehu Refera, Tadesse Gebremedhin and Mengistu Huluka (1993). Laboratory and field evaluation of $B$. thuringiensis Berliner var. kurstaki on African Bollworm Helicoverpa armigera (Hunber). Proceedings of the first Annual Conference of Crop Protection Society of Ethiopia 14-15 April 1993. Addis Ababa, Ethiopia.

4. Altschul, S.F., Madden, T.L., Schaffer, A.A., Zhang, J., Zhang, Z., Miller, W. and Lipman, D. (1997). Gapped BLAST and PSI_blast: a new generation of protein database search programs. Nucleic Acids Res. 25:3389-3402.

5. Ben-Dov, E., Zaritsky, A., Dahan, E., Barak, Z., Sinai, R., Mansherob, R., Khamraev, A., Trioskaya, E., Dubitsky, A., Berezina, N. and Margalith, Y., (1997). Extended screening by PCR for seven cry-group genes from field-collected strains of B. thuringiensis. Appl. Environ. Microbiol. 63:4883-4890. 
6. Bernhard, K., Jarrett, M., Meadows, M., Butt, J., Ellis, J., Roberts, G., Pauli, S., Rodgers, P. and Brges, H.D. (1997). Natural isolates of $B$. thuringiensis: world wide distribution, characterization, and activity against insect pests. J. Invertebr. Pathol. 70:59-68.

7. Blackwood, K.S., Turenne, C.Y., Harmsen, D. and Kabani, A.M. (2004). Reassessment of sequence-based targets for identification of Bacillus species. J. Clin. Microbiol. 42:1626-1630.

8. Bravo, A., Sarabia, S., Lopez, L., Ontiveros, H., Abarca, C., Ortiz, A., Oritz, M., Lina, L., Villobos, F.J., Pena, G., Nunez-Vadez, A.E., Soberon, M. and Quintero, R. (1998). Characterization of cry genes in Mexican Bacillus thuringiensis strain collection. Appl. Environ. Microbiol. 66:4965-4972.

9. Bronikowski, A.M., Bennett, A.F. and Lenski, R.E. (2001). Evolutionary adaptation to temperature. VIII. Effect of temperature on growth rate in natural isolates of Escherichia coli and Salmonella enterica from different therma environments. Evolution. 55:33-40.

10. Carozzi, N.B., Krmer, V.C., Warsen, G.W., Evola, S. and Koziel, M. (1991). Prediction of insecticidal activity of B. thuringiensis strains by polymerase chain reaction product profiles. Appl. Environ. Microbiol. 52:30573061.

11. Cavado, C.F.G., Fonseca, R.N., Chaves, J.Q., Rabinovitch, L. and Araujo-Coutinho, C JPC. (2001). Identification of entomopathogenic Bacillus isolated from Simulium (Diptera, Simulidae) larvae and adults. Mem Inst Oswaldo. Cruz, Rio dejanerio.96:1017-1021.

12. Chilcott, C.N. and Wigley, P.J. (1988). Technical notes: an improved method for differential staining of B. thuringiensis crystals. Lett. Appl. Microbiol. 7:67-70.

13. Chilcott, C.N. and Wigley, P.J. (1993). Isolation and toxicity of $B$. thuringiensis from soil and insect Habitats in New Zealand. J. Invertebr. Pathol. 61:244-247.

14. DelGiorgio, P.A., Bird, .F, Prairie, Y.T. and Planas, D. (1996). Flowcytometric determination of bacterial abundance in lake plankton with the nucleic acid stain SYTO13. Limnol.Oceanogr.41:865-789.

15. Goto, K., Omura, T., Hara, Y. and Sadaie, Y. (2000). Application of the partial 16S rDNA sequence as an index for rapid identification of species in the genus Bacillus. J. Gen. Appl. Microbiol. 46:1-8.
16. Hansen, B.M., Damgaard, P.H., Eilenberg, J. and Pedersen, J.C. (1998). Molecular and phenotypic characterization of $B$. thuringiensis isolated from leaves and insects. J. Invertebr. Pathol. 71:106-114.

17. Helgason, E., Okstad,O.A., Caugant, D., Johansen, H., Fouet, A., Mock, M., HengaI. and Kolsto, A.B. (2000). Genetic structure of population of Bacillus cereus and $B$. thuringiensis isolates associated with periodontitis and other human infections. J. Clin. Microbiol. 38:16151622.

18. Ibarra, E. and Federici, B.A. (2003). Isolation of a relatively non toxic 65-kilodalton protein inclusion from the parasporal body of Bacillus thuringiensis israelensis. J. Bacteriol. 165:527533.

19. Lane, D.J. (1991). 16S/23S rRNA sequencing. In Nucleic acid Techniques in Bacterial Systematics, pp. 115-175. , (Stackebrandt, and Goodfellow, M. eds). Wiley and Sons, Chichester.

20. MOA (2000). Agro-ecological Zones of Ethiopia. Natural Resources Management and Regulatory Department, Ministry of Agriculture, Addis Ababa. Sept., 2000, pp. 129.

21. Porter, A.G., Davidson, E.W. and Weilliu, U.J. (1993). Mosquitocidal toxins of bacilli and their genetic manipulation for effective biological control of mosquitoes. Microbiol. Rev. 57:838-861.

22. Rangni, A., Thiery, I. and Delecluse, A. (1996). Characterization of six highly mosquitocidal B.thuringiensis strains that do not belong to $\mathrm{H}$ 14 sero type. Curr. Microbiol. 32:48-54.

23. Rasko, D.A, Altherr, M.R., Han, C.S., Ravel, Jacques and Ravel, J. (2005). Genomics of the B.cereus group organisms. FEMS Microbiol. Rev. 29:303-329.

24. Shi, B. and Xia, X. (2003). Changes in growth parameters of Pseudomonas pseudoalcaligenes after ten months culturing at increasing temperature. FEMS Microbial. Ecol. 45:127-134.

25. Smith, R. A. and Couche, G. A. (1991). The phylloplane as a source of $B$. thuringiensis variants. Appl. Environ. Microbiol. 57:311-315.

26. Strunk, O. and Ludwig, W. (1996) ARB: A software environment for sequence data, 2.1.1 Munich. Department of Microbiology, Technical University of Munich.

27. Travers, R.S., Martin, A.W. and Reichelderfer, C.F. (1987). Selective process for efficient isolation 
of soil Bacillus sp. Appl. Environ. Microbiol. 53:1263-1266.

28. Vergin, K.L., Urbach, E., Stein, J.L., DeLong, E.F., Lanoil, B.D. and Giovannoni, S.J. (1998). Screening a fosmid library of marine environmental genomic DNA fragments reveals four clones related to members of the order Planctomycetales. Appl Environ Microbiol 64:3075-3078.

29. Yoo, K.H., Kim, S.Y., Kang, M.H., Cho, M.H. and Lee, H.H. (1996). Characterization of $B$. thuringiensis isolates from soil in Wonju Area. J. Microbiol. 34:370-37. 